\title{
PROTOTYPESISTEM PELAYANAN PUBLIKDINASKEPENDUDUKAN DAN CATATAN SIPILBERBASISWEB
}

\author{
David Budi Hartanto, S.Kom \\ Universitas Pesantren Tinggi Darul Ulum \\ Jombang, , Indonesia \\ dvdbudil@gmail.com
}

\begin{abstract}
ABSTRAK
Kepuasan masyarakat sangat perlu diperhatikan oleh aparat untuk mengetahui kualitas pelayanan yang baik. Inilah yang menjadi salah satu tugas dari Dinas Kependudukan dan Catatan Sipil (dispendukcapil). Sistem yang ada di dinas tersebut lebih terfokus pada proses pembuatan,sedangkan untuk pelayanan misalnya pendaftaran sering terjadi lonjakan jumlah antrian yang relatif besar dan mengakibatkan tidak terlayaninya permohonan dengan baik. Prototype sistem pelayanan ini dirancang untuk menambah nilai pelayanan dinas kepada masyarakat. Prototype sistem yang dibangun ini mempunyai fitur diantaranya permohonan pengajuan Akta Kelahiran, Kartu Tanda Penduduk dan Kartu keluarga. Apabila petugas menyetujui pengajuan maka pemohon menerima jadwal validasi atau verifikasi sehingga pemohon mengetahui status pengajuan dan kepastian waktu proses validasi atau verifikasi yang harus dilakukan. Prototype sistem pelayanan berbasis web ini dapat digunakan oleh dinas untuk mengatur penjadwalan pengajuan dokumen kependudukan dan dapat bermanfaat bagi masyarakat dalam mengetahui tingkat kepastian dari proses pengajuan yang telah dilakukan.
\end{abstract}

Kata Kunci:Dispendukcapil, sistem pelayanan, jadwal, web.

\begin{abstract}
Satisfaction of community is very need to be considered by officials to know the good service quality. This has become one of the tasks of the Office of Population and Civil Registration (dispendukcapil). Systems the existing in the agency more focused on manufacture process, while for eg the registration service often occur hikes the number of queues that relatively large and result not served the petition by either. Prototype service system is designed to add value service agencies to the community. The prototype constructed system has features among others the petition submission of a birth certificate, National Identity Card and Family Card.when the officers approve the submission of then the applicant receives schedule the validation or verification so that the applicant know the the filing status and certainty of validation time or verification process that must performed.Prototype web-based service system can be used by the department for scheduling the filing of civil documents and can be beneficial to the community in knowing the the level of certainty of the process of filing which have been carried out.
\end{abstract}

Keywords:Dispendukcapil, system service, schedule, web 


\section{Pendahuluan}

Pada dasarnya setiap manusia
membutuhkan pelayanan, $\begin{array}{r}\text { bahkan } \\ \text { secaraekstrim dapat dikatakan bahwa } \\ \text { pelayanan tidak dapat dipisahkan } \\ \text { dengankehidupan }\end{array}$

Masyarakatsetiap waktu selalu menuntut pelayanan publik yang berkualitas dari birokrat, meskipun tuntutan tersebut sering tidak sesuaidengan harapan. Kecenderunganseperti itu terjadi karena masyarakat masih diposisikan sebagai pihak "melayani”"bukan yang dilayani. Hal ini menimbulkan dampak buruk terhadapperkembangan kualitas pelayanan (Sinambela,2006).

Kepuasan masyarakat sangat perlu di perhatikan oleh aparat demi pemberian pelayanan untuk mengetahui kualitas pelayanan yang baik. Inilah yang menjadi salah satu tugas dari Dinas Kependudukan dan Catatan Sipil misalnya di bidang pelayanan dokumen kependudukan. Usaha-usahapun telah dilakukan mulai penataan ruang yang nyaman dan fasilitas yang menunjang untuk mempermudahkan petugas melakukan pekerjaan dengan menerapkan sistem yang telah terkomputerisasi. Sistem komputerisasi yang ada di pelayanan lebih terfokus pada proses pembuatan. Sedangkan untuk pelayanan misalnya pendaftaran sering terjadi jumlah antrian yang panjang.

Berikut adalah kutipan jurnal mengenai masalah administrasi kependudukan dalam pendaftaran kelahiran di Indonesia: "Enam dari sepuluh anak di bawah usia lima tahun di Indonesia tidak diakui keberadaannya secara sah oleh Pemerintah Indonesia. Anak-anak ini tidak memiliki identitas secara sah yang dituangkan dalam akta kelahiran. Padahal, akta kelahiran memiliki arti penting bagi eksistensi anak sebagai warga negara di muka hukum. Ironisnya, menurut data SUSENAS 2007, hanya 42 persen anak di bawah usia lima tahun (0-4 tahun) yang memiliki akta, sisanya 58 persen belum memiliki akta kelahiran" (Kementrian Pemberdayaan Perempuan dan Anak RI:2009).

Salah satu solusi dari masalah di atas adalah dengan dibangunya sebuah prototype sistem pelayanan yang dapat digunakan secara online untuk melakukan pengajuan dokumen kependudukan, yang dimaksud prototype di sini adalah sebagai model awal dari suatu sistem yang akan ditingkatkan terus menerus sesuai kebutuhan pemakai sistem.Sistem pelayanan publik di dinas kependudukan dan catatan sipil dapat membantu dan meningkatkan pelayanan dinas kepada masyarakat, serta petugas dapat menjadwalkan atau mengatur waktu pengambilan dokumen kependudukan sehingga masyarakat atau pemohon mendapat suatu kepastian untuk memvalidasi pengajuan dokumennya.

\section{Dinas Kependudukan Dan Catatan Sipil}

Penyelenggaraan Catatan Sipil pada jaman Pemerintah Hindia Belanda ditangani oleh Lembaga "Burgerlijk Stand" atau disingkat "BS" yang artinya Catatan Kependudukan/Lembaga Catatan Sipil. Lembaga Catatan Sipil adalah "suatu lembaga yang bertujuan mengadakan pendaftaran, pencatatan serta pembukuan yang selengkap-lengkapnya dan sejelasjelasnya, serta memberi kepastian hukum yang sebesar-besarnya atas peristiwa "kelahiran, pengakuan, perkawinan dan kematian". (Hock, 1961:1).Sedangkan E. Subekti dan R. Tjitrosoedibio berpendapat, 
bahwa "Catatan Sipil mempunyai pengertian sebagai suatu lembaga yang ditugaskan untuk memelihara daftar atau catatan guna pembuktian status atau peristiwa penting bagi warga negara seperti : "kelahiran, kematian, perkawinan". Pada masa pemerintahan Hindia Belanda, kantor Burgerlijk Stand (Kantor Catatan Sipil) bertugas mencatat keadaan penduduk dari segi kelahiran, perkawinan dan kematian. Selanjutnya pemerintah Hindia Belanda mewajibkan semua warga golongan eropa mendaftarkan diri atas peristiwa kelahiran, perkawinan, perceraian dan kematian (Staatblad 1849 No.25). Melalui upaya ini pemerintah Hindia Belanda dapat mengetahui secara pasti berapa banyak orang Eropa dan berapa pertambahannya.

Banyak sekali dokumen-dokumen yang dikerjakan oleh dinas kependudukan anrata lain : akta kelahiran, kartu keluarga, kartu tanda penduduk, dan lain-lain. Akta Kelahiran adalah bukti mengenai status dan peristiwa kelahiran seseorang yang dikeluarkan oleh Dinas Kependudukan dan Catatan Sipil.Bayi yang dilaporkan kelahirannya akan terdaftar dalam kartu keluarga dan diberi Nomor Induk Kependudukan (NIK) sebagai dasar untuk memperoleh pelayanan masyarakat lainnya. Dari pusat layanan publik untuk indonesia menjelaskan bahwa KTP Elektronik adalah dokumen kependudukan yang memuat sistem keamanan / pengendalian baik dari sisi administrasi ataupun teknologi informasi dengan berbasis pada database kependudukan nasional. Penduduk hanya diperbolehkan memiliki 1 (satu) KTP yang tercantum Nomor Induk Kependudukan (NIK). NIK merupakan identitas tunggal setiap penduduk dan berlaku seumur hidup. Sedangkan Kartu Keluarga adalah kartu identitas keluarga yang memuat data tentang susunan, hubungan dan jumlah anggota keluarga kita. Wajib dimiliki oleh setiap keluarga, kartu ini berisi data lengkap mengenai identitas Kepala Keluarga beserta anggota keluarganya. Kartu keluarga dicetak rangkap 3, yang masing-masing dipegang oleh Kepala Keluarga, Ketua RT, Kantor Kelurahan, dan Suku Dinas.

\section{Tugas Pokok Dispenduk Capil.}

Tugas pokok dan fungsi organisasi merupakan landasan dari satu instansiuntuk melaksanakan tugas dan wewenangnya. Berdasarkan Keputusan Bupati Jombang No. 26 tahun 2001 telah dijabarkan Tupoksi Jabatan structural pada Kantor Kependudukan dan Catatan Sipil Kabupaten Jombang. Tugas pokok dari Kantor Kependudukan dan Catatan Sipil adalah "Membantu Bupati dalam menyelenggarakan sebagian kewenangan daerah dibidang Kependudukan dan Catatan Sipil“".

\section{Fungsi Dispendukcapil}

Adapun fungsi Kantor Kependudukan Dan Catatan Sipil kabupatenjombang adalah sebagai berikut : a. Perumusan kebijakan tentang perencanaan teknis pembangunan danpengendalian dibidang Kependudukan, Catatan Sipil yang meliputi :Administrasi Kependudukan Dan Catatan Sipil.

b. Perumusan dan pemantauan kegiatan pelayanan kepada masyarakat dibidangKependudukan Dan Catatan Sipil. c. Pengawasan pelaksanaan bimbingan, penyuluhan dan pengendalian teknisdibidang administrasi Kependudukan dan Catatan Sipil. 
d. Perumusan dan penyusunan petunjuk teknis Perundang - undangan yangberkaitan dengan kegiatan yang meliputi bidang Kependudukan, pelayananakta - akta Catatan Sipil, penyuluhan dan evaluasi dalam rangka penyusunandata dan pelaporan.

e. Pelaksanaan koordinasi dan kerjasama dengan instansi terkait dibidangKependudukan Dan Catatan sipil.

f. Pelaksanaan pengelolaan ketata usahaan.

g. Pelaksanaan tugas - tugas lain yang diberikan oleh Bupati melalui

SekretarisDaerah.

\section{Standar Pelayanan Publik (SPP)}

Pengertian pelayanan menurut Kotler dalam Sinambela (2006:4) adalah "setiap kegiatan yang menguntungkan dalam suatu kumpulan atau kesatuan dan menawarkan keputusan meskipun hasilnya tidak terkait pada suatu produk secara fisik". Pelayanan publik dapat didefinisikan sebagai serangkaian aktivitas yang dilakukan oleh birokrasi publik untuk memenuhi kebutuhan masyarakat (Dwiyanto, 2005:141), bahwa pelayanan umum merupakan kegiatan yang dilakukan oleh pemerintah dalam memenuhi kewajibannya, akan tetapi tidak disebabkan oleh hal itu saja melainkan pemerintah memang harus memberikan pelayanan kepada masyarakat.

Secara Teoritis, tujuan pelayanan publik pada dasarnya adalah memuaskan masyarakat untuk mencapai kepuasan itu dituntut kualitas pelayanan prima yang tercermin dari asas-asas pelayanan publik berdasarkan Surat Keputusan Mentri Pendayagunaan Aparatur Negara Nomor (Kepmen PAN) No.63 Tahun 2003, dalam sinambela (2006:5) yaitu : a. Transparasi, yaitu bersifat terbuka, mudah dan dapat diakses oleh semua pihak yang membutuhkan dan diseiakan secara memadai serta mudah dimengerti

b. Akuntabilitas, yaitu dapat dipertanggungjawabkan sesuai dengan ketentuan peraturan perundang-undangan.

c. Kondisional, yaitu sesuai dengan kondisi dan kemampuan pemberi dan penerima pelayanan dengan tetap berpegang pada prinsif efisiensidan efektivitas.

d. Partisipatif, yaitu mendorong peran serta masyarakat dalam penyelenggaraan pelayanan publik dengan memperhatikan aspirasi, kebutuhan dan harapan masyarakat.

e. Kesamaan Hak, yaitu tidak diskriminatif dalam arti tidak membedakan suku, ras, dan agama, golongan, gender dan status ekonomi

f. Keseimbangan Hak dan Kewajiban : pelayanan yang mempertimbangkan aspek keadilan antara pembeli dan penerima pelayanan

\section{Analisis Sistem}

Pada analisis sistem ini digunakan untuk menggambarkan analisis kejadian atau sistem yang sedang berjalan pada dinas kependudukan dan catatan sipil dan sisitem pelayanan publik yang dibangun. Pada Dinas Kependudukan dan Catatan Sipil proses pendaftaran dilakukan secara manual dengan sistem antrian, pemohon yang akan datang meminta form permohonan dokumen kepada petugas, setelah itu pemohon diminta mengisi form pengajuan dokumen dan diminta melengkapi dokumen persyaratan pengajuan, kemudian pemohon diminta mengumpulkan dokumen pengajuan dan mengambil nomer antrian. Selama 
mengantri petugas akan memvalidasi pengisian data dan dokumen persyaratannya, apabila pengajuan sudah benar maka pemohon akan di beri form untuk pengambilan dokumen, dan apabila masih ada kesalahan maka pemohon harus membenahi kesalahanya dan kembali mengantri sampai permohonan tersebut benar dan divalidasi petugas.

Untuk gambaran sistem pelayanan publik adalah sebagai berikut, sistem berjalan secara online, dispenduk capil ini merupakan sebuah prototype media web untuk melakukan permohonan dokumen kependudukan masyarakat. Pada sistem ini pemohon harus memiliki login, apabila tidak memiliki maka pemohon dapat membuat user login terlebih dahulu. Setelah melakukan login pemohon memilih jenis pengajuan, dan mengisi form tersebut serta melengkapi dokumendokumen yang telah di scan kemudian diupload pada website ini. Data permohonan tadi akan di proses dan diterima oleh dinas berupa pengajuan yang akan divalidasi, setelah data sudah memenuhi syarat maka pemohon akan menerima sebuah form validasi, dengan form tersebut pemohon mendapatkan kepastian bahwa dokumen yang diajukannya sudah benar dan diterima oleh dinas, setelah itu pemohon dapat datang ke dinas dan memvalidasi pengajuan dokumennya.

Pada Dinas Kependudukan dan Catatan Sipil proses pendaftaran dilakukan secara manual dengan sistem antrian, pemohon yang akan datang meminta form permohonan dokumen kepada petugas, setelah itu pemohon diminta mengisi form pengajuan dokumen dan diminta melengkapi dokumen persyaratan pengajuan, kemudian pemohon diminta mengumpulkan dokumen pengajuan dan mengambil nomer antrian. Selama mengantri petugas akan memvalidasi pengisian data dan dokumen persyaratannya, apabila pengajuan sudah benar maka pemohon akan di beri form untuk pengambilan dokumen, dan apabila masih ada kesalahan maka pemohon harus membenahi kesalahanya dan kembali mengantri sampai permohonan tersebut benar dan divalidasi petugas.

\section{Sistem yang diusulkan}

Sistem online dispenduk capil ini merupakan sebuah prototype media web untuk melakukan permohonan dokumen kependudukan masyarakat. Berikut gambaran rich picture dari sistem yang akan dibuat.

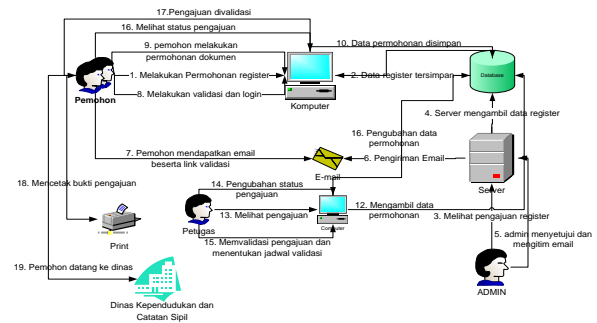

Gambar 1.Rich Picture Proses Sistem

Gambar 1 : Pada program ini pemohon harus memiliki login, apabila tidak memiliki maka pemohon dapat membuat user login terlebih dahulu. Setelah melakukan login pemohon memilih jenis pengajuan, dan mengisi form tersebut serta melengkapi dokumen-dokumen yang telah di scan kemudian diupload pada website ini.Data permohonan tadi akan di proses dan diterima oleh dinas berupa pengajuan yang akan divalidasi, setelah data sudah memenuhi syarat maka pemohon akan menerima sebuah form validasi, dengan form tersebut pemohon mendapatkan kepastian bahwa dokumen yang diajukannya sudah benar dan diterima oleh 
dinas, setelah itu pemohon dapat datang ke dinas dan memvalidasi pengajuan dokumennya.

\section{Definisi Kebutuhan}

Dalam melakukan pembuatan sistem maka dibutuhkan beberapa data sebagai berikut :

Tabel 1 : data input dibutuhkan untuk data awal yang akan diproses untuk kebutuhan dokumen-dokumen yang diperlukan.

Tabel 1. Tabel Kebutuhan Input

\begin{tabular}{|l|l|}
\hline \multicolumn{1}{|c|}{ Input } & \multicolumn{1}{|c|}{ Keterangan } \\
\hline $\begin{array}{l}\text { Data } \\
\text { Register }\end{array}$ & $\begin{array}{l}\text { Digunakan untuk membuat } \\
\text { membuat user baru untuk } \\
\text { pengajuan dokumen }\end{array}$ \\
\hline $\begin{array}{l}\text { Data } \\
\text { form } \\
\text { pengajua } \\
\text { nerisi pentanyaan tentang } \\
\text { pembuatan dokumen yang } \\
\text { diisi oleh pemohon }\end{array}$ \\
\hline $\begin{array}{l}\text { Data } \\
\text { Scan } \\
\text { atau } \\
\text { gambar }\end{array}$ & $\begin{array}{l}\text { Data ini di perlukan sebagai } \\
\text { syarat pengajuan pembuatan } \\
\text { dokumen }\end{array}$ \\
\hline
\end{tabular}

Tabel 2 : Data kebutuhan proses berasal dari data input yang di olah yang kemudian akan menghasilkan output sesuai kebutuhan.

Tabel 2 Tabel Kebutuhan Proses

\begin{tabular}{|l|l|}
\hline \multicolumn{1}{|c|}{ Proses } & \multicolumn{1}{|c|}{ Keterangan } \\
\hline $\begin{array}{l}\text { Memasukka } \\
\text { p data diri } \\
\text { pemohon }\end{array}$ & $\begin{array}{l}\text { Proses memasukan ini } \\
\text { untuk pembuatan } \\
\text { username dan password } \\
\text { untuk pemohon }\end{array}$ \\
\hline $\begin{array}{l}\text { pengajuan } \\
\text { dokumen }\end{array}$ & $\begin{array}{l}\text { Proses ini di lakukan } \\
\text { untuk membuat } \\
\text { pengajuan kepada dinas } \\
\text { dengan mengisi data } \\
\text { dan persyaratan secara } \\
\text { lengkap }\end{array}$ \\
\hline $\begin{array}{l}\text { Validasi } \\
\text { pengajuan }\end{array}$ & $\begin{array}{l}\text { Proses dilakukan oleh } \\
\text { admin dengan melihat } \\
\text { apakah data yag } \\
\text { dimasukkan telah sesuai } \\
\text { dan semua syarat telah }\end{array}$ \\
\hline
\end{tabular}

\begin{tabular}{|l|l|}
\hline & terpenuhi \\
\hline Tabel $3:$ Kebutuhan outputmerupakan
\end{tabular} sebuah hasil berupa print out dan laporan mengenai pengajuan yang dilakukan pemohon.

Tabel 3. Tabel Kebutuhan Output

\begin{tabular}{|l|l|}
\hline \multicolumn{1}{|c|}{ Output } & \multicolumn{2}{|c|}{ Keterangan } \\
\hline $\begin{array}{l}\text { Laporan } \\
\text { formPengajuan }\end{array}$ & $\begin{array}{l}\text { Berisi laporan form } \\
\text { pengajuan beserta } \\
\text { syaratnya sebagai } \\
\text { arsip dinas }\end{array}$ \\
\hline Form Validasi & $\begin{array}{l}\text { Sebuah form yang } \\
\text { menunjukkan } \\
\text { pemohon dapat } \\
\text { mengvalidasi } \\
\text { permohonanya ke } \\
\text { dinas. }\end{array}$ \\
\hline
\end{tabular}

\section{Hasil Penelitian}

Metode ini digunakan untuk menguji hasil perancangan. Berikut tampilan beranda dari sistem pelayanan publik dinas kependudukan.

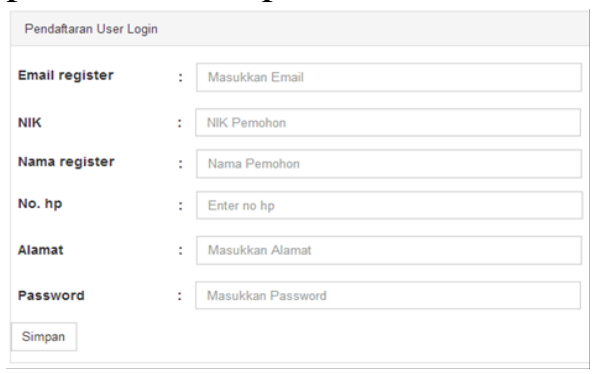

Gambar 2.Halaman Register

Gambar 2 : Sebelum User dapat mengakses suatu pengajuan maka user harus melakukan register atau pengajuan user agar dapat memperoleh akses pemohon. 


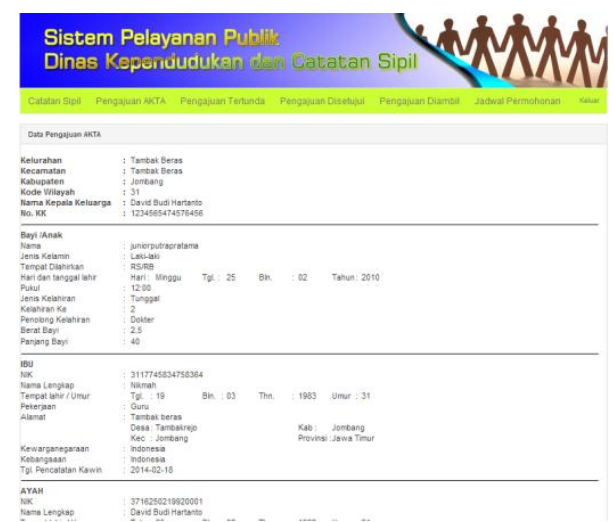

Gambar 3.Halaman Hasil Input Data

Gambar 3 : Saat melakukan pengajuan pemohon diminta untuk mengisikan datadata, Halaman ini merupakan hasil dari semua nputan data yang di view.

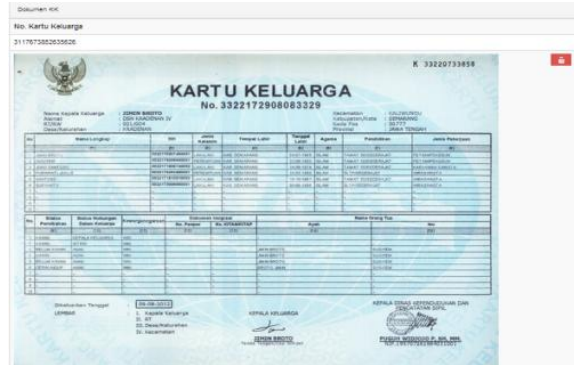

Gambar 4. Halaman Upload Gambar

Gambar 4 : Dalam pengurusan dokumen kependudukan dibutuhkan upload beberapa dokumen gambar sebagai bukti kebenaran data pengajuan yang dilakukan dan nantinya sebagai arsip untuk pihak dinas.

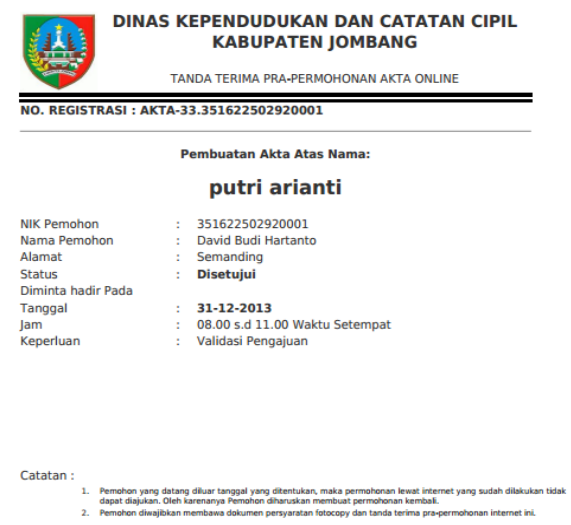

Gambar 5.Dokumen Validasi

Gambar 5 : Pada pengajaun terdapat pada menu pengajuan di setujui, pada tombol
printPemohon dapat mengklik dan mendapatkan form validasi tersebut, form tersebut bisa langsung dicetak atau disimpan, form pengajuan tersebut sebagai tanda bukti bahwa pengajukan telah divalidasi oleh petugas dan permohonanya dapat diajukan kepada dinas untuk ditindak lanjuti.

\section{Kesimpulan}

Dari pembahasan sistem maka dapat disimpulkan sebagai berikut bahwa Sistem pelayanan publikini sistem ini dapat melakukan pendaftaran secara online dan multiuser. Prototype Webpelayanan publik dinas kependudukan dan catatan sipil dapat mengatur jadwal permohonan pengajuan dokumen kependudukan, dimana pemohon mendapatkan kepastian tentang jadwal pengajuanya dan pemohon mengetahui kepastian untuk melakukan validasi/verifikasi pengajuan, sehingga pelayanan dinas akan lebih optimal karena meningkatkan pelayanan dan mendapatkan kepercayaan dari penduduknya.

\section{Daftar Pustaka}

Asmuni, I. (2006). Kajian Teoritis Pendekatan Prototyping dan Relevansinya Terhadap Perkembangan Sistem Informasi Bisnis , 49-51.

Fowler, Martin. 2005. UML Destilled 3th Ed. Panduan Singkat Bahasa Pemodelan Objek Standar. ANDI. Jogjakarta. 
Khairani, S. I. (2012). Efektifitas Pasal 9 Peraturan Daerah Kota Malang Nomor 15,5 .

Kristaung, R. (2011). Metodologi penelitian sistem informasi dan manajemen informatika. Jakarta: Mitra wacana media. 
